\title{
THE IRISH QUESTION
}

AND BRITISH POLITICS 1868-1986 


\title{
British History in Perspective General Editor: Jeremy Black
}

\author{
PUBLISHED TITLES
}

D. G. Boyce The Irish Question and British Politics 1868-1986

A. J. Pollard The Wars of the Roses

Robert Stewart Party and Politics, 1830-1852

FORTHCOMING TITLES

C. J. Bartlett British Foreign Policy in the Twentieth Century

John Davis British Politics 1885-1931

John Derry British Politics in the Age of Pitt

Ann Hughes Causes of the English Civil War

Diarmaid MacCulloch Religion and Society 1547-1603

Michael Prestwich English Politics in the Thirteenth Century 


\title{
THE IRISH QUESTION AND BRITISH POLITICS 1868-1986
}

\author{
D. G. BOyCE
}


(C) D. G. Boyce 1988

Softcover reprint of the hardcover 1st edition 1988

All rights reserved. For information, write:

Scholarly \& Reference Division,

St. Martin's Press, Inc.,

175 Fifth Avenue, New York, NY 10010

First published in the United States of America in 1988

ISBN 978-0-333-40598-7 ISBN 978-1-349-19578-7 (eBook)

DOI 10.1007/978-1-349-19578-7

Library of Congress Cataloging-in-Publication Data

Boyce, David George, 1942-

The Irish question and British politics, 1868-1986/D.G. Boyce,

p. $\quad \mathrm{cm} .-$ (British history in perspective)

Bibliography: $p$.

ISBN 978-0-312-02478-9: $\$ 35.00$ (est.)

1. Ireland-Politics and government-20th century. 2. IrelandPolitics and government-1837-1901. 3. Northern Ireland-Politics and government-1969- 4. Great Britain-Politics and government-20th century. 5. Great Britain-Politics and government-1837-1901. 6. Great Britain-Foreign relationsIreland. 7. Ireland-Foreign relations-Great Britain. 8. Irish question. I. Title. II. Series.

DA959.569 1988

$941.608-\mathrm{dc} 19$

88-21140

CIP 


\section{CONTENTS}

Preface vii

Maps viii

Acknowledgements - x

Introduction The Oldest Question: Ireland in British 1 Politics and History

1 A Question of Definition, 1868-1908: Gladstonian 18 Reform, Home Rule and the Unionist Response

2 A Question of Partisanship, 1909-22: British Party 44 Politics, the Great War and Ireland

3 A Question of Containment, 1923-49: Britain, the two 72 Irelands and the Commonwealth

4 A Question of Bipartisanship, 1950-86: British Politics 99 and the Northern Ireland Problem

Conclusion A Question for Britain 
Bibliographical and Historiographical Essay

Appendices

Index

152 


\section{PREFACE}

This is not yet another book about the 'Irish Question'. If it were it would (depending on the point of view) be much longer, and concerned with timeless verities like morality, justice and possibly original sin. Or shorter, since most of life in Ireland since life began there is not, contrary to popular opinion, concerned with 'Questions' - or even questions. This book is concerned with a theme that is at once wider and narrower than the Irish experience. It traces the role of Irish political affairs in British politics, and the response of British politicians to these as they impinged upon their world. It offers no model, colonial, quasi-colonial, neo, post or any other colonial. It avoids discussions of abstractions which owe more to the current state of Irish political conflict than to the realities of the Anglo-Irish relationship. Nevertheless, like all history, it is influenced by the time and conditions in which it is written. Historians are becoming aware of the need to redefine and reconsider what often passes for British (in reality English or even southern English history) and it is hoped that this book will make a small contribution to that large, and long overdue, exercise. 


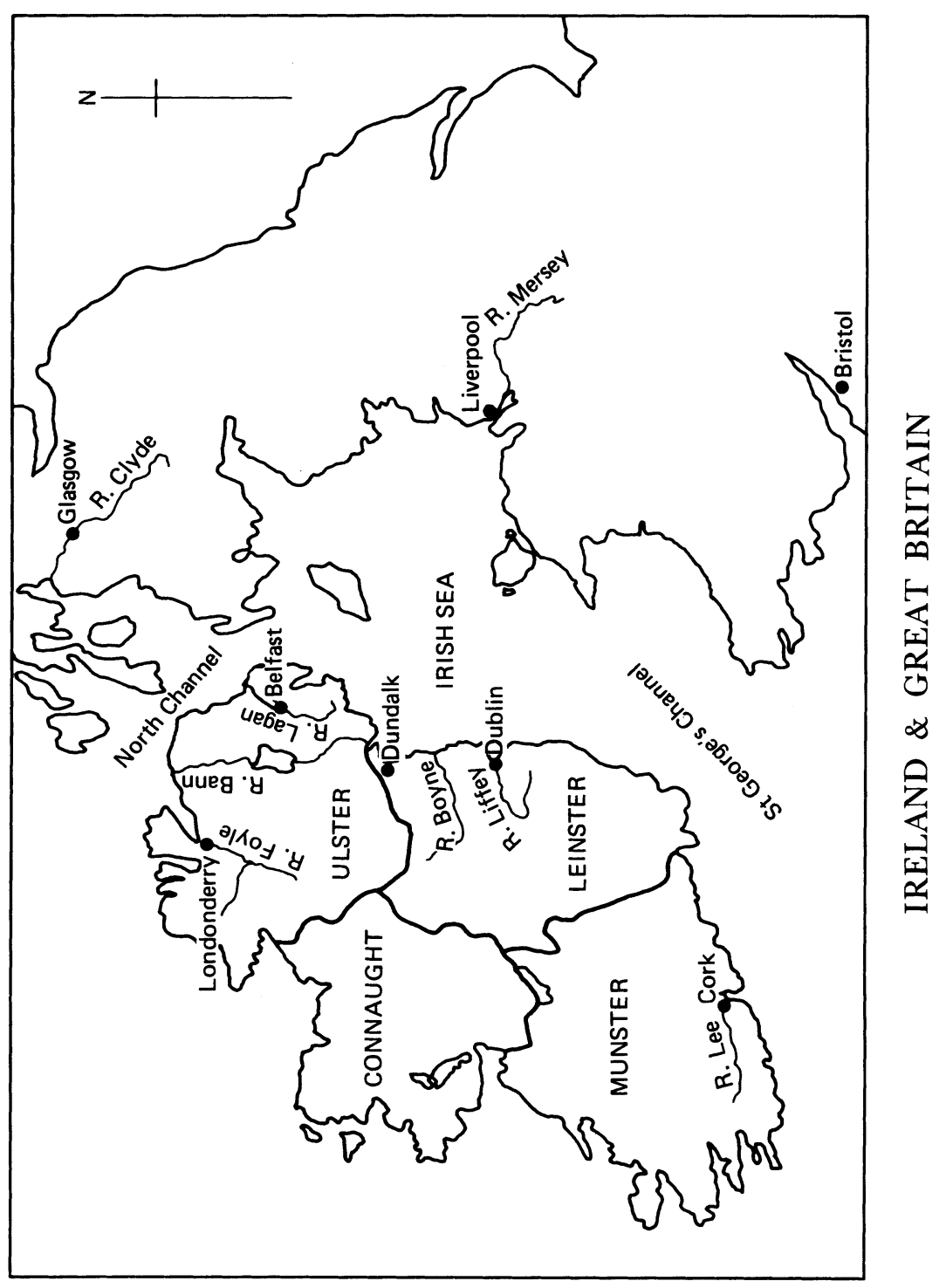




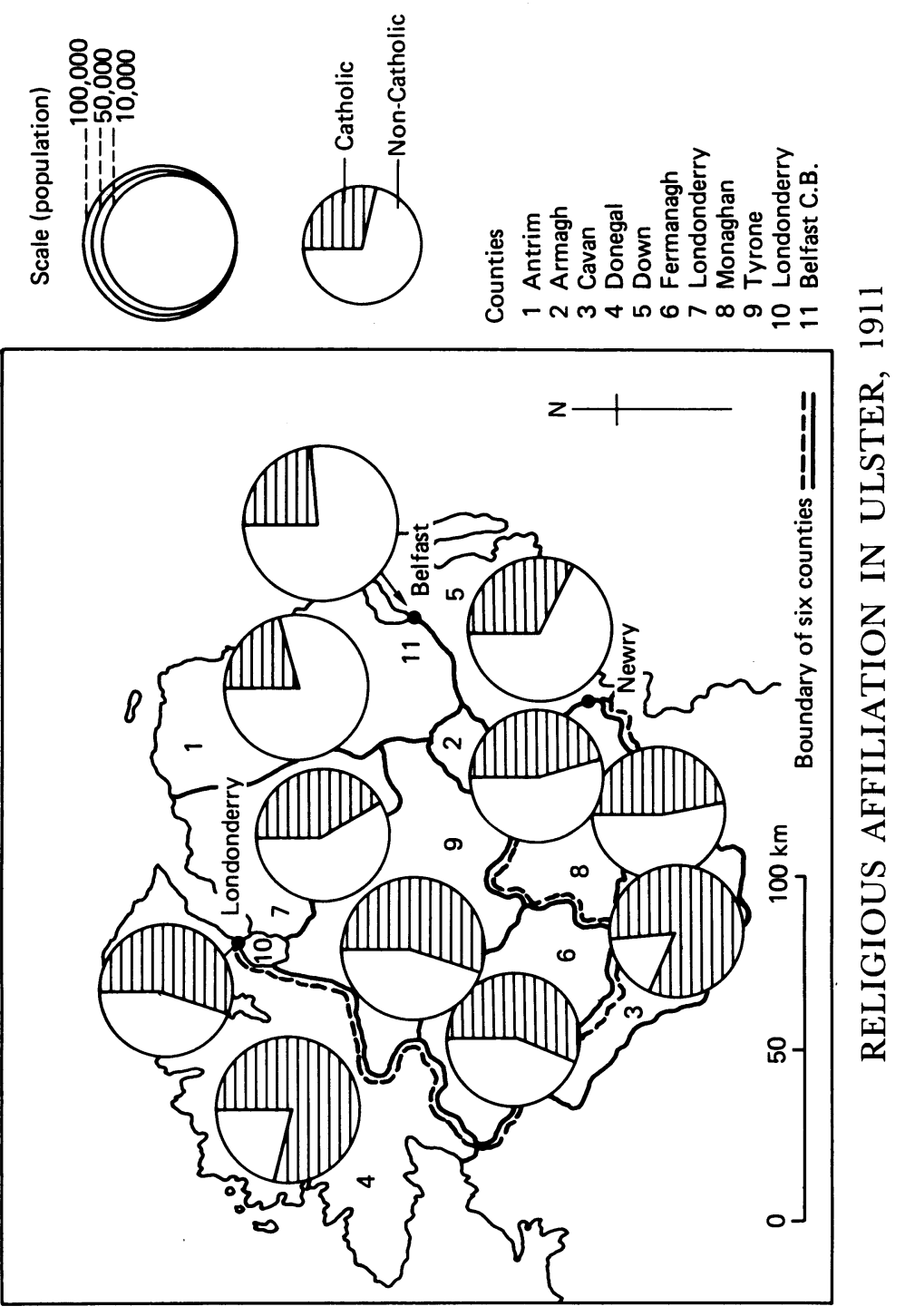




\section{ACKNOWLEDGEMENTS}

I am grateful to Mrs Pat Yates, Mrs Judith Gilbody and Mrs Phyllis Hancock for typing and retyping the manuscript, to Mr Chris Ince for designing and drawing the maps and to my family for their support. This book is for Patrick Buckland to thank him, however insufficiently, for his help and inspiration in Irish studies over some twenty years.

D. G. Boyce, September 1987 
What then is the duty of an English Minister? To effect by his policy all those changes which a revolution would effect by force.

(Benjamin Disraeli)

Much difference of opinion prevails as to ... what the people of England could be brought to consent, and what the people of Ireland would be content to receive.

(Charles Greville)

Ireland under the Act of Union represented the government of one people through the public opinion of another.

(T. P. O’Connor) 